\title{
Strategy for Preparation of Indonesian Language Teaching Materials for Distance Learning at SMK Negeri 1 Salatiga
}

\author{
Yusuf Candra, Sarwiji Suwandi, Budhi Setiawan
}

Sebelas Maret University, Surakarta, Indonesia

Received: 09 Oct 2021; Received in revised form: 19 Nov 2021; Accepted: 28 Nov 2021; Available online: 07 Dec 2021

(C)2021 The Author(s). Published by Infogain Publication. This is an open access article under the CC BY license

(https://creativecommons.org/licenses/by/4.0/).

\begin{abstract}
Teaching materials are prepared as a reference and guideline by the teacher, as well as a reflection of the teacher's evaluation which is highly effective in observing the quality of learning in the classroom. This study aims to describe how the strategy of preparing Indonesian language teaching materials in distance learning at SMK Negeri 1 Salatiga. This research uses descriptive qualitative research. The research design used is a case study. The data and sources of this research are data on strategies for preparing Indonesian language teaching materials in distance learning.The data source comes from the Indonesian language teacher at SMK Negeri 1 Salatiga. Data collection techniques in this study include observation, interviews, and documentation. The data validity technique uses source triangulation. The data analysis technique uses the Milles and Huberman interactive model. The results obtained in this study are strategies in compiling teaching materials in distance learning, including:(1) identifying learning problems, (2) analyzing student character, (3) analyzing assignments (4) formulating indicators, (5) compiling learning materials, (6) formulating learning strategies, (7) choosing appropriate learning resources, ( 8) compiling assessment instruments, (9) compiling formative and summative evaluations, (10) conducting supporting services, (11) revising learning tools
\end{abstract}

Keywords—strategies, teaching materials, Indonesian, distance learning.

\section{INTRODUCTION}

Teaching material is a tool that is systematically arranged which has a function as a reference and guide by the teacher in conveying the material or basic competencies being taught. As stated by (Heinich, R., 2002) teaching materials are learning tools that must be arranged systematically and contain competencies to be achieved or mastered by students, so that later they can provide knowledge to students.Because the existence of teaching materials can build students' confidence and belief in learning the material being taught. Therefore, it is necessary to design and develop teaching materials with strategies that are adapted to the environmental community around students(Grellet, 2010) and (Prastowo, 2017).

Teaching materials become a mirror of teacher evaluation that is highly effective in observing the quality of learning in the classroom. These qualities can be known through student learning outcomes (Richard, J. C., \& Redanandya,2002). Another function of teaching materials for teachers is to facilitate educators in reflecting, evaluating, and developing materials. Thus, the material presented to students can be in accordance with good learning targets(Hamalik, 2019).

The benefits of teaching materials in Indonesian language learning aim to improve students' language skills as well as a means of instilling dictative values (Saleh, 2015). According to the Ministry of Education and Culture (in Saleh, 2015) states that, there are several important objectives in the preparation of teaching materials 1) provide teaching materials that are in accordance with the demands of the curriculum by considering the needs of students, namely teaching materials that are in accordance with the characteristics and background or social environment of students, 2) assist students in obtaining 
alternative teaching materials in addition to textbooks which are sometimes difficult to obtain, and 3) make it easier for teachers to carry out learning. Indonesian language teaching materials. Based on the statement above, essentially the principle of good learning is to increase competence, expand students' knowledge, shape attitudes or character, hone skills, and provide learning experiences(Suwandi, 2018).

The case of the Covid-19 pandemic that hit Indonesia had a significant impact on various sectors, one of which was in the education sector. Nevertheless, the learning process must continue to run well, namely the teacher can continue to carry out his obligations as educators while students get their rights to learn. Therefore, the learning process that was previously carried out face-to-face has transformed into distance learning or online learning. Distance learning is an indirect learning activity, the learning of which utilizes various learning resources through information technology, communication, and other media(Herliandry, 2020). This learning relies on media (text, hypertext, graphics, audio, animation, and video) and written, visual, or spoken human products that can be accessed in an integrated manner through multimedia and computers(Lamy, M. N., \& Hampel, 2007).

The teaching and learning process continues even though the students are at home. As stated in the Decree of the Minister of Education and Culture of the Republic of Indonesia about Circular Letter Number 4 of 2020 concerning the Implementation of Education Policies in the Emergency Period for the Spread of Covid-19. Various initiatives were carried out to ensure that learning activities continued even in the absence of face-to-face sessions(Baety, Dwinda Nur dan Munandar, 2021); (Asmuni, 2020); and (Dewi, 2020).

In distance learning, adjustments are needed including: learning methods, learning media, learning techniques, and teaching materials used in distance learning. In the current distance learning process, books and teaching materials are an important source of information to increase knowledge and motivation to learn(Sya'diyah, 2021). For a teacher, innovative strategies are needed in preparing teaching materials and utilizing the right technology, so that the information provided to students can be absorbed properly and maximally (Fazilla, 2020). Therefore, teachers must have the ability to help students to keep learning, and have in-depth proficiency in the material they are studying(Hammond, 1997).

The criteria for good teaching materials can be classified as follows: (1) good teaching materials have appeal and increase interest for students who use them. (2)
Provide motivation to students who use it. (3) Contains illustrations that are attractive to those who use them. (4) consider linguistic or linguistic aspects. (5) Closely related to other lessons. (6) Can stimulate, stimulate the personal activities of students. (7) Avoiding vague and unusual concepts so as not to confuse students. (8) Having a clear and firm point of view or point of view so that in the end it becomes the point of view of loyal users. (9) Provide stabilization, emphasis on the values of students. (10) Good teaching materials should be able to appreciate the personal differences of the students who use them. (Greene dan Petty in (Guntur Tarigan, 1986)).

Many studies related to the preparation of Indonesian teaching materials have been carried out, one of which is (Arif, 2018). The research found several important procedures that must be carried out by educators in the preparation of teaching materials, including: (1) it is necessary to pay attention to content standards and graduate competency standards, syllabus, semester programs, and learning implementation plans; (2) the need to identify the types of learning materials; (3) the teacher must map the materials taught to students; (4) Determining the form of presentation of teaching materials; (5) The teacher prepares the structure (framework) for the presentation of teaching materials that will later be taught; (6) Looking for references from various sources; (7) making draft teaching materials; (8) making revisions or editing of teaching materials; (9) conducting trials of teaching materials; and the last (10) revising and writing the final (finalization).

Another study conducted by Wikanengsih et al (2019) stated that in compiling teaching materials, it must be based on theories relevant to communication competencies, namely by paying attention to the development of linguistic, sociolinguistic, discourse, and communication strategies competencies. In the perspective of preparing Indonesian teaching materials, constructivism, whole language, communicative, integrative, and contextual perspectives can be used. Based on the five perspectives, it is supported by language skills.

Based on the explanation above, the researcher wants to describe how the strategy for preparing Indonesian language teaching materials in distance learning at SMK Negeri 1 Salatiga is. SMK Negeri 1 Salatiga is a leading state vocational high school. Researchers have obtained initial data that during the pandemic the Indonesian language teachers at the school had prepared creative and innovative teaching materials.In addition, the teacher has adapted to the situation and conditions in the field, namely by making learning innovation breakthroughs such as the use of learning media such as: Microsoft Teams, Google Classroom, etc. 
as a support for learning activities during the pandemic. The teaching materials used by teachers are also considered to be relatively varied by adjusting each material in each of their basic competencies.

\section{METHOD}

This study uses a qualitative descriptive method, in which this study explores the problems that exist around the community by involving various important efforts, such as asking questions and procedures, collecting data specifically from participants, analyzing data inductively, and interpreting the meaning of the data (J. W Creswell, 2019). The strategy of this research is a case study with the place of research at SMK Negeri 1 Salatiga. Case studies are empirical approaches to investigate phenomena in depth which include inquiry, logic, data collection techniques, and specific data analysis approaches(Yin, 2018:46). The data used in this study is a strategy for preparing Indonesian language teaching materials by teachers in distance learning. Sources of data were obtained from Indonesian language teachers at SMK Negeri 1 Salatiga. Data collection techniques were carried out by observation, interviews, and documentation. The data validity technique uses source triangulation. The data analysis technique uses the Milles and Huberman interactive model.

\section{RESULT AND DISCUSSION}

Teaching materials are a set of materials that are systematically arranged and used to carry out learning activities in the classroom (Dick, 2009). Several strategies for preparing teaching materials can be used as the basis for teachers in compiling distance learning. Strategies for preparing teaching materials according to Kemp et al (1994) include: 1) identification of learning problems; 2) conducting an analysis of the characteristics of students; 3 ) analyzing the task; 4) formulating indicators of the material being taught; 5) preparing learning materials; 6) choosing a learning strategy; 7) determine the right learning media; 8) preparing assessment instruments; 9) identifying the willingness of learning resources; 10) paying attention to supporting services; 11) compiling assessments (formative and summative) in teaching materials; 12) revising the teaching materials that have been developed.

\section{Identification of Learning Problem}

Identifying problems, the gap between the objectives in the applicable curriculum and the facts that occur in the field is very much needed in compiling a teaching material. As stated by one of the
Indonesian language teachers in the following data excerpt.

Before we arrange teaching materials, we usually discuss together with the school's Indonesian Language Subject Teacher Conference first. Usually we discuss any obstacles, then what needs we need. We happen to be taking shelter (teaching) in a vocational school, so we need to adjust it to SMK. (Indonesian teacher class XI, 8/9/2021).

We also need to adapt today' learning. We are also having online learning. So, when we give the material, of course we adjust it to the current conditions. We adjust to the conditions of the emergency curriculum. In the emergency 2013 curriculum, the teacher can figure out the basic competencies (KD) content to be studied. (Indonesian teacher class XII 4/ 8/2021).

The identification of learning problems has been carried out by the teacher by conducting needs analyzes that will be included in the teaching materials. Teachers actualize through school Subject Teacher Conference activities during the preparation of teaching materials. In their activities, the teacher analyzes the applicable curriculum.In addition, the teacher also analyzes the syllabus and basic competencies that will be taught to students. Considering that learning is done online, the teacher provides alternatives and solutions in conveying basic competencies.

The context of the social environment is also especially important to be considered by the teacher in the preparation of teaching materials. Because, the meaning of a teaching material is very influential on the natural, social, and cultural conditions of students. In other words, the content of the material in the teaching materials is more familiar to the students, the more students understand what the teacher is saying, and vice versa, the dreamier it is, the more difficult it is for students to understand what is conveyed by the teacher in compiling learning in a teacher's vocational school must be able to be relevant or related to the student's area of expertise. For example, students majoring in culinary arts learn about procedural texts, then the teacher must be able to present materials related to culinary arts.

\section{Analysis of Student Characteristics}

Knowing the characteristics of students which include characteristics, abilities, and experiences both individually and in groups. Characteristic analysis is also related to the minimum competency standards or 
qualifications owned by students. As stated by one of the Indonesian language teachers in the interview, the following is an excerpt of the data:

It is even especially important that we study (analyze) the characteristics of students when compiling teaching materials. Considering that it has been almost 2 years we have studied virtually, so the analysis of student characteristics is not optimal. We usually see from the assignments that students collect. from there we can know the student's shortcomings (Indonesian teacher class XI, 8/9/2021)

The learning experience is closely related to how, what about, in what way, and from which learning sources, and in what context students can learn. The experience of students is not only to find out how far the student is learning, but also how skilled and grow certain attitudes that are relevant to the events they are learning.

In the preparation of teaching materials during the Covid-19 pandemic, the teacher adapts to the experiences of students. Teachers usually insert materials related to the topic or issue of Covid-19. In this regard, students have gained experience related to information that has been heard or read. Based on this, students can live and experience themselves, so that the teaching materials learned are more meaningful

Indonesian language teachers conduct analysis activities on student characteristics, one of which is by giving assignments. In the teacher's task, the teacher conveys the phenomena that are happening currently. Based on the tasks collected, the teacher evaluates the tasks given, then from there the teacher can find out the strengths and weaknesses of each student. In addition, the teacher can find out the obstacles. For example, there are students who are diligent in doing assignments and there are also students who are often late for assignments.

\section{Analysis of Assignment}

Assignment analysis is a procedure for detailing the content of subjects in the form of an outline to master the content of the study material or learn skills that include cognitive skills, psychomotor skills, and social skills. The purpose of task analysis in teaching materials is to figure out a teaching content, analyze concepts, analyze information processing, and procedural analysis to facilitate understanding and proficiency in learning tasks and learning objectives as outlined in the lesson plan and student worksheets, as stated in the following interview data excerpt.
When compiling teaching materials, we also analyze the content in them. In addition to do the analysis, we select the information that we will include (present) in the learning material. We check first, whether the material that we will use later is possible or not or there is something that needs to be fixed. Then whether it is relevant to the core competence $(K I)$ and basic competence (KD) that we designed or not. We need to pay attention to that too. (Indonesian teacher class XII, 4/8/2021).

Assignments that we use in teaching materials, of course, we adjust to the abilities of students. For example, children majoring in marketing and accounting in our office are not evenly matched. Different. That's an example. Then like the content in it (teaching materials) we also pay close attention to: assignment instructions, structured assignments, projects, portfolios. (Indonesian teacher class XI, 8/9/2021).

Based on the data above, the teacher has conducted an analysis of the organization of teaching materials. A teaching material should be a meaningful unit. Therefore, the presentation must be systematic or sequential. Good teaching materials certainly have structured elements, including: introduction, content and closing.

The introduction section begins with general information, such as general goals to be achieved after studying the material being taught, how to use teaching materials, and how to work on practice assignments or questions. The next step deals with content. At this step, selecting the material, presenting the material, and using language and legibility as the content of the book.In the selection of materials, the teacher has made innovations by using interesting materials. The last step is closing the teacher using exercises or summative tests as a comprehensive picture of students' abilities (cognitive, psychomotor, and affective)

\section{Formulating Indicators}

Designing learning activities, frameworks in evaluating student learning outcomes and student guidance in learning. One thing that a teacher can do is formulate indicators in teaching materials. The activity of formulating indicators of achievement of the competencies taught is one of the important competencies carried out by a teacher. Indicator of competency achievement, one of the means to figure out focus and accuracy in learning activities. 
Good teaching materials must contain indicators of competency achievement. This is because indicators of competency achievement become a benchmark for the success of students in mastering a basic competency being studied. As stated by one of the Indonesian language teachers at SMK Negeri 1 Salatiga.

When we compose teaching materials, we write down indicators of competency achievement in them. What's the reason? Later when students or users of teaching materials can understand what indicators we will achieve (Indonesian teacher class XI,8/9/2021).

Today's example we study the explanatory text of KD 4.3. construct information in the explanatory text. Of course, there are indicators achieved by students. We also put it on the teaching materials, so that later students understand (Indonesian teacher class XII ,4/8/2021).

Based on the interview excerpt above that in the preparation of teaching materials the teacher pays attention to indicators of competency achievement. The teacher also socializes the indicators both when giving the material and writing it down on the jar materials prepared by the teacher. Competency achievement indicators are formulated based on Basic Competencies. In its use the teacher uses language that is short, clear, and effective, so that later it can be understood by users of teaching materials. The language used does not contain multiple meanings. The indicators compiled by the teacher use operational verbs that are easy to measure. It is no less important to pay attention to the characteristics of Indonesian subjects, the potential of students, and the contextual environment of the school.

\section{Preparing Learning Materials}

The ability to compile and determine learning materials for the content of teaching materials is a crucial point for a teacher in learning activities. The preparation of the material is closely related to the syllabus and basic competencies because they are interrelated. Because the designed teaching materials include planning, projecting what will be conveyed to students. In the preparation of the material being taught, it is necessary to pay attention to the order of the contents of the subject based on the prerequisite knowledge, familiarity, difficulty, interest and student development. as the results of the data obtained from the following interviews.

When we compose teaching materials, we use a lot of references, either from books from the
Ministry of Education and Culture or from other handbooks, modules. We also adjust vocational materials (vocational competence areas). For example, procedural material, we make material related to majors (Indonesian teacher class XII, 4/8/2021.

In the preparation of teaching materials, we adjust them to the competency areas in this school (SMK Negeri 1 Salatiga). Incidentally, we are a vocational school, like it or not, we must follow (relevant) vocational material (cooking, beauty, office accounting, marketing, and fashion). If I, I am in the culinary department, then my material is adjusted to the culinary arts (Indonesian teacher class XI, 8/9/2021).

Based on the results of the interviews above, it shows that the teacher has prepared the subject matter, namely by showing valuable information, knowledge, skills, or values that are arranged in such a way as to make it easier for students to understand the material being taught.

The teacher has also conducted a study of the teaching materials. Because teaching materials are the main object of analysis after indicator analysis. Therefore, the subject matter becomes the most important reference in the preparation of teaching materials. In this way, the learning objectives are achieved optimally.

\section{Learning Strategies}

Choose teaching and learning strategies that are in accordance with the objectives.

Of course, when compiling teaching materials there are strategies that we use. Each of the materials has a variety of strategies. It is just a matter of what material we will teach (Indonesian teacher class XII, 4/8/2021).

Of course, we use strategies in which we put the strategy into the teaching materials that we compile. If each material we use a relatively varied strategy. Even when we deliver in each $K D$ (Basic Competence) we use a different strategy (Indonesian teacher class XI 8/9/2021).

In composing of teaching materials, the teacher has used a strategy. The strategy itself is the chosen way to deliver learning material, so that later it can be easily understood by students. In relation to the composing of teaching materials, teachers have used strategies to make it easier for learning activities, considering that at this time learning is carried out online, there are obstacles faced by educators, both 
technical and non-technical. Therefore, the methods used by the teacher can facilitate the transformation of knowledge to students.

\section{Selection of Learning Resources}

The purpose of this step is to select media or learning resources according to the demands of the learning objectives. The success of learning is highly dependent on the use of the selected learning resources and media.

In the selection of learning resources, we usually look for on the internet such as: Google, YouTube, Socmed (social media). We also get learning resources from books, such as teacher's books, then there are handbooks. We use many sources. Anyway, what we have, we use (Indonesian teacher class XII, 4/8/2021 and Indonesian teacher class XI, 8/9/2021).

Based on the excerpt above, the teacher has selected and reviewed the learning resources. In selecting learning resources, the teacher pays attention to several aspects, including: availability, suitability, and convenience. On the aspect of the willingness of teachers to try to provide learning resources that are practical, economical, so that they are extremely easy to provide. For example, teachers provide learning resources from the internet, because the internet is rich in available information. On the other hand, students also use smartphones a lot and internet assistance packages are also available from the Ministry of Education and Culture during distance learning.

The teacher also provides learning resources that are in accordance with the learning objectives. In this case the teacher chooses the competencies to be achieved by students. Furthermore, the aspect of convenience, educators have tried to use learning resources that are easy to use and extremely easy to provide.

\section{Assessment Instruments}

Develop assessment instruments to assess learning outcomes based on specific learning objectives that have been formulated so that the criteria used are benchmark reference assessments.

Assessment instruments on teaching materials include assessment of attitudes, knowledge, and skills. In the teaching materials there are assignments for evaluation. Of course, we provide assessment instruments that are in accordance with the current 2013 curriculum (Indonesian teacher class XII, 4/8/2021 and Indonesian teacher class XI, 8/9/2021).

In the preparation of teaching materials, the teacher composes an assessment instrument which includes attitude assessment, knowledge assessment, and skills assessment. The function of the assessment instrument is as a benchmark or reference in evaluating learning.

Aspects of assessment designed by teachers are adapted to the 2013 curriculum with the aim of strengthening students' competencies from the affective, cognitive, and psychomotor aspects. The assessment instrument prepared by the teacher is also structured to measure students' abilities. In addition, the teacher also adjusts the material being taught.

\section{Support Service}

In the preparation of teaching materials, the teacher is very attentive to the availability of budget, facilities, materials, equipment, the ability of staff, teachers, and learning designers. In compiling teaching materials, usually the school holds IHT (In House Training) activities to the teacher council. Usually, these activities are held at the beginning of the new semester.

These activities facilitate teachers in developing competencies. One of the activities is usually the preparation of creative teaching materials. Especially during the current pandemic, In House Training activities are especially important, because they equip teachers to be professional, innovative, and creative in carrying out learning activities. Especially when preparing creative and interesting teaching materials.

\section{Formative and Summative Evaluation}

Formative assessment is an assessment with the aim of evaluating the extent to which students' ability to understand the material that has been delivered. This assessment is carried out after each unit of the learning process is completed to provide information to the teacher or development team how well the program is achieving its goals. While the summative assessment is an assessment used to assess the extent to which the instructional objectives have been achieved at the end of the learning program.

In the teaching materials prepared by the teacher there are assignments or questions that must be finished and discussed by students. In this case the Indonesian language teacher at SMK Negeri 1 Salatiga has given structured assignments, so that they can be controlled properly. The existence of these tasks as an evaluation of the learning that has been 
done. Next, the teacher has also provided summative evaluations at the end of the learning program. it is important for teachers to conduct such evaluations, especially at this time learning that is only done virtually can be used as material for evaluation and development of the arrangement of teaching materials.

\section{Revising Learning Tools}

Evaluate and improve learning tools that are developed continuously at every step of its development.

We always evaluate and develop the teaching materials we have used. However, for revisions, we do not all make revisions. Maybe if we need to revise, we will make revisions, but if we do not need, we also do not revise (Teacher of Indonesian class XII, 4/8/2021).

Especially from me, often updating the materials. With the aim of students getting new information. Moreover, we are being hit by the Covid-19 pandemic, we also take materials or materials related to Covid-19 and Indonesian Language Teachers (class XI, 8/9/2021).

In relation to the preparation of teaching materials, teachers make innovations that are adapted to the current situation.As the excerpt above, when the teacher presents the text as the content of the teaching material the teacher takes the topic of the material related to the pandemic problem. This is a form of innovation carried out by teachers by updating the teaching materials they have prepared.

\section{CONCLUSION}

Teaching materials have a key role in learning activities. In addition to functioning to facilitate teachers in teaching, teaching materials are used as references and learning guidelines. Based on the discussion above, it can be concluded that Indonesian language teachers in distance learning have made a breakthrough which is actualized through strategies in preparing teaching materials including:(1) identifying learning problems, (2) analyzing student character, (3) analyzing assignments (4) formulating indicators, (5) compiling learning materials, (6) formulating learning strategies, (7) choosing appropriate learning resources, ( 8) compiling assessment instruments, (9) compiling formative and summative evaluations, (10) conducting support services, (11) revising learning tools.

\section{REFERENCES}

[1] Arif, A. T. dan I. (2018). Teknik Penyusunan Bahan Ajar Bahasa Indonesia bagi Guru di Sekolah Dasar. Prosiding Seminar Nasional Pendidikan, 597-606.

[2] Asmuni, A. (2020). Problematika Pembelajaran Daring di Masa Pandemi Covid-19 dan Solusi Pemecahannya. Jurnal Paedagogogy, 7(4), 281-288.

[3] Dewi, W. A. . (2020). Dampak Covid-19 terhadap Implementasi Pembelajaran Daring di Sekolah Dasar. Edukatif. Jurnal Ilmu Pendidikan, 2(1), 55-61.

[4] Fazilla, S. (2020). Kemampuan Analisis Masalah Mahasiswa PGMI dalam Pembelajaran Daring (Online) pada Masa Covid 19. PIONIR: Jurnal Pendidikan, 9(2), 51-62.

[5] Grellet, F. (2010). Developing Reading Skills. Cambridge University Guilford Press.

[6] Guntur Tarigan, H. (1986). Menyimak Sebagai Suatu Keterampilan Berbahasa. Angkasa.

[7] Hamalik, O. (2019). Kurikulum \& Pembelajaran. Bumi Aksara.

[8] Hammond, D. \& L. (1997). Doing What Matters Most: Investing in Quality Teaching. National Commission on Teaching \& America's Future.

[9] Heinich, R., et a. (2002). Instructional Media and Technologies for Learning. Pearson Merrill Prentice Hall. Upper Saddle.

[10] Herliandry, L. D. et al. (2020). Pembelajaran Pada Masa Pandemi Covid-19. Jurnal Teknologi Pendidikan, 22(1), 65-70.

[11] J. W Creswell. (2009). Research design: Qualitative, quantitative, and mixed methods approaches. SAGE Publications, Inc.

[12] Lamy, M. N., \& Hampel, R. (2007). Online Communication in Language Learning and Teaching. Palgrave Macmillan.

[13] Prastowo, A. (2017). Panduan kreatif membuat bahan ajar inovatif. Diva Press.

[14] Richard, J. C., \& Redanandya, W. A. (2002). Methodology in Language Teaching: An Anthology of Current Practice. In Methodology in Language Teaching: An Anthology of Current Practice. UK.

[15] Saleh, M. (2015). Pengembangan Bahan Ajar Bahasa Indonesia Berbasis Kurikulum 2013 yang Mengintegrasikan Nilai Karakter Bangsa di SMP Muhammad. Jurnal Pendidikan Dan Pembelajaran, 22(2), 117-129.

[16] Suwandi, S. (2018). Peran Guru dalam Mengimplementasikan Pembelajaran Bahasa Indonesia Berbasis pada Kebutuhan Siswa. Seminar Nasional Bahasa, Sastra, Dan Pengajarannya, 1-9.

[17] Sya'diyah, K. (2021). Pengembagan E-Modul Berbasis Digital Flipbook untuk Mempermudah Pembelajaran Jarak Jauh di SMA. Edukatif: Jurnal Ilmu Pendidikan, 3(4), 1298-1308.

[18] Yin, R. K. (2018). Case Study Research and Applications Design and Methods (Sixth Edit). SAGE. https://doi.org/10.1177/109634809702100108. 